University of Nebraska - Lincoln

DigitalCommons@University of Nebraska - Lincoln

Robert G. Fuller Publications and Presentations Research Papers in Physics and Astronomy

August 1975

\title{
Teaching-the purpose of repeatable testing: Response to comment of J. D. Edmonds
}

\author{
D.E. Golden \\ University of Nebraska - Lincoln \\ Robert Fuller \\ rfuller@neb.rr.com \\ D.D. Jensen \\ University of Nebraska - Lincoln
}

Follow this and additional works at: https://digitalcommons.unl.edu/physicsfuller

Part of the Physics Commons

Golden, D.E.; Fuller, Robert; and Jensen, D.D., "Teaching-the purpose of repeatable testing: Response to comment of J. D. Edmonds" (1975). Robert G. Fuller Publications and Presentations. 7.

https://digitalcommons.unl.edu/physicsfuller/7

This Article is brought to you for free and open access by the Research Papers in Physics and Astronomy at DigitalCommons@University of Nebraska - Lincoln. It has been accepted for inclusion in Robert G. Fuller Publications and Presentations by an authorized administrator of DigitalCommons@University of Nebraska - Lincoln. 
one need ever know how much we struggled to make it or how others performed in comparison. (Isn't education a certification of competency to practice-uh, what was it?) In fact, by replacing teachers with computerprogrammed instruction and testing, only the computer will ever know (and it can be programmed to self-destruct that part of the tape).

But this is all very expensive. Since there is getting to be a shortage of "science majors," why not just have the students sign in at the door of the lecture hall each day? At the end of the semester a clerk certifies to the registrar that student A attended better than $90 \%$ of the lectures. When he has "attended" the required courses (and electives), we give him an "Attended Degree." He is happy. He learned what he wanted and ignored the rest. The de- partment meets its FTE quotas, so everyone's job is secure. The instructor has "good friendly relations" with the students, and they with each other. The teach-person is a helper, counselor, friend. No confrontations or haggling over points. No traumas. It is all so sensible. Why go halfway to utopia with retesting? If an employer or grad school wonders who to hire, that is their problem! Let colleges flower into serenity. What's that you say? "Real World?" How did you get in here?

*Present address: Department of Joint Sciences, Claremont Colleges, Claremont, CA 91711.

'D. E. Golden, R. G. Fuller, and D. D. Jensen, Am. J. Phys. 42, 941 (1974).

\section{Teaching - the purpose of repeatable testing: Response to comment of J. D. Edmonds}

\author{
D. E. Golden \\ R. G. Fuller \\ D. D. Jensen \\ Department of Physics \\ University of Nebraska-Lincoln \\ Lincoln, Nebraska 68508 \\ (Received 20 December 1974)
}

It is not clear that the comment "Grading and Regrading" " has very much to do with our article. ${ }^{2}$ The comment seems rather to be a nostalgic statement recalling the good old days when with glee we cracked the whip and the students either shaped up or shipped out.

Our purpose in doing repeatable testing was not to become a "do your own thing" force, to raise everyone's grades, to "achieve well defined educational objectives" like teaching the solution to the inclined plane problem, to do away with certification, and most definitely our purpose was not to replace teachers with computerprogrammed instruction.

Our purpose was in fact really rather simple. It was to try to teach more physics. Dr. Edmond's comment has not addressed the premise of our paper, which is that people learn from their mistakes (even in the real world). We have used nothing but the old guard establishment tool of testing as a measure of content mastery. Once the test is established as the measure of content mastery, how large a jump is it to the statement that if you do better on the next exam you will have mastered more content? If we can improve the teaching of physics and make the students feel good about learning at the same time, we should be willing to give up a few of our old sadistic pleasures.

In spite of the logic of it all, one still might not believe that students learn more by repeatable testing. Perhaps in the future we might attempt to answer the question at the output by using testing as a measuring tool. We might divide a large group and allow only half of the group to repeat exams during the course. We could then give a common comprehensive final exam to the whole group and look at the results.

We recognize the existence of the "Final Day of Judgment" approach to physics instruction whereby physics is used to separate the sheep from the goats for later rewards such as a Ph.D. in physics, or an engineering degree, or entrance into medical school. We wish to encourage a "Pierian Spring" approach to physics in which students are encouraged to drink repeatedly to sober their brains and improve their reasoning skills.

${ }^{1} \mathrm{~J}$. D. Edmonds, Jr., the preceding letter, Am. J. Phys. 43, 745 (1975).

${ }^{2}$ D. E. Golden, R. G. Fuller, and D. D. Jensen, Am. J. Phys. 42, 941 (1974). 